\title{
A TRADUÇÃO DE TEXTOS CIENTÍFICOS NO PERÍODO DA EXPANSÃo MARÍTIMA, UMA HISTÓRIA EM CONSTRUÇÃO \\ Cristina de Amorim MACHADO
}

A proposta deste trabalho é apresentar alguns resultados atualizados sobre o papel da tradução na expansão marítima. Minha hipótese é a de que a tradução teve um papel de destaque nesse empreendimento ibérico, sobretudo na transmissão dos textos científicos antigos. Para corroborar essa hipótese, apresentarei alguns personagens prestigiados do período das descobertas, mas que raramente são lembrados por suas práticas tradutórias: Pedro Nunes, Abraão Zacuto, José Vizinho, João Faras e André do Avelar. Essas reconhecidas figuras da história da ciência inscrevem-se definitivamente na história da tradução.

Palavras-chave: tradução científica, expansão marítima, história da ciência, história da tradução

THE TRANSLATION OF SCIENTIFIC TEXTS DURING IBERIAN MARITIME EXPANSIONISM: A HISTORY UNDER CONSTRUCTION

The purpose of this paper is to discuss the role of translation in the Iberian maritime expansionism. My hypothesis is that translation had an important role in this Iberian enterprise, particularly in the transmission of ancient scientific texts. Corroborating the established hypothesis, I will present a number of important characters in the Era of Discoveries, who are seldom remembered for their translation practices: Pedro Nunes, Abraham Zacuto, José Vizinho, João Faras and André do Avelar. These famous characters of the maritime expansionism can also be seen as important personages in the history of translation.

Keywords: scientific translation, maritime expansionism, history of science, history of translation

\section{MANOEL JACINTO NOGUEIRA DA GAMA: CIÊNCIA E TRADUÇÃO NO FINAL DO SÉCULO XVIII}

\section{Alessandra Ramos de Oliveira HARDEN}

No final do século XVIII, ocorreu em Portugal um fenômeno caracterizado pela publicação de grande número de obras traduzidas em áreas como matemática, química e biologia. Um dos tradutores envolvidos nesse movimento foi o brasileiro Manoel Jacinto Nogueira da Gama, futuro Marquês de Baependi, ministro da fazenda e signatário da Constituição de 1824. Neste artigo, o objetivo é examinar os prefácios que Nogueira da Gama escreveu para suas traduções, no que se refere às suas opiniões sobre as relações entre tradução, língua e ciência no contexto do Iluminismo Português. Palavras-chave: história da tradução; tradução técnico-científica; iluminismo lusobrasileiro; Manoel, Jacinto Nogueira da Gama; prefácios do tradutor.

\section{MANOEL JACINTO NOGUEIRA DA GAMA: SCIENCE AND TRANSLATION AT THE END OF THE 18TH CENTURY}

At the turn of the 19th century, Portugal witnessed the publication of a large number of translated works in areas such as mathematics, chemistry and biology. One of the translators involved in this scientific translation boom was the Brazilian-born Manoel Jacinto Nogueira da Gama, future Marquis of Baependi, Minister of Finance, who also 
signed the first Brazilian Constitution, which came into force in 1824. In this article, an analysis is made of the prefaces written by Nogueira da Gama for his translations, examining his opinions on translation, language and the science of the Portuguese Enlightenment.

Keywords: translation history; technical and scientific translation; Luso-Brazilian enlightenment; Manoel Jacinto Nogueira da Gama; translator's prefaces.

\section{O PAPEL DA TRADUÇÃO NA PESQUISA CIENTÍFICA BRASILEIRA: PRIMEIROS MOVIMENTOS Cristina Carneiro RODRIGUES}

Este trabalho tem como objetivo traçar caminhos para verificar qual foi o papel das traduções na construção da ciência brasileira. O percurso inicia-se com 0 estabelecimento das universidades como centros de investigação científica e sua relação com a expansão editorial na Era Vargas, especialmente com a publicação de coleções de obras não-ficcionais. Em um segundo momento, examinam-se textos de "Coleções Brasilianas” publicadas na época, para buscar referências ao uso de traduções. Por fim, analisam-se textos sobre a história das ciências no Brasil para comprovar o uso efetivo de traduções, na Era Vargas, como fonte de referência para pesquisadores de várias áreas do conhecimento, desde a botânica e a biologia, até a história e as geociências.

Palavras-chave: História da Tradução, Coleção Brasiliana, pesquisa, Era Vargas.

\section{THE ROLE OF TRANSLATION IN BRAZILIAN SCIENTIFIC RESEARCH: FIRST MOVEMENTS}

The purpose of this article is to outline ways to study the role translation played in the construction of Brazilian science. This begins with the establishment of the universities as scientific research centers and their relationship with the publishing expansion in the Vargas Era, especially with the publication of non-fictional works. Secondly, texts from "Coleções Brasilianas", published during this period, are examined to find references on the use of translations. Finally, texts on the history of science in Brazil are analyzed in order to confirm the use of translations in the Vargas Era as a reference source for researchers in a number of areas, from Botany and Biology to History and Geosciences. Keywords: Translation History, Brasiliana Collection, research, Vargas Era.

\section{UGO FOSCOLO E AS DISCUSSÕES SOBRE A TRADUÇÃO DOS CLÁSSICOS NA ITÁLIA ENTRE OS SÉCULOS XVIII E XIX Karine Simoni}

A partir da relação entre vida da obra, tradução e história, proposta por Benjamin no ensaio A tarefa-renúncia do tradutor, o artigo trata de aspectos da história da tradução dos clássicos na Itália nos séculos XVIII e XIX, de modo a apresentar um panorama das aproximações e embates entre os principais tradutores do período, como Cesarotti, Monti e Foscolo. Destaca também o pensamento de Foscolo e as suas principais 
contribuições para os estudos da tradução em relação aos seus predecessores e aos seus contemporâneos.

Palavras-chave: Ugo Foscolo, tradução dos clássicos, séculos XVIII e XIX, história da tradução.

\section{UGO FOSCOLO AND THE DISCUSSION ON THE TRANSLATION OF THE CLASSICS IN ITALY BETWEEN THE 18TH AND 19TH CENTURIES}

This article considers the relationship between the history of a work, its translation, literature, and history as proposed by Benjamin in "The Task of the Translator". The article then details the history of translation of the classics in Italy in the 18th and 19th centuries and the discussions of important translators in the period such as Cesarotti, Monti and Foscolo, highlighting Foscolo's approach and his contributions to translation studies in relation to his predecessors and contemporaries.

Keywords: Ugo Foscolo, translation of the classics, 18th and 19th centuries, history of translation.

\section{OS TRADUTORES DO QUIXOTE PUBLICADOS NO BRASIL Silvia COBELO}

Este trabalho reúne a história dos seis tradutores do Quixote publicados no Brasil desde a primeira edição da obra em 1942 até 2008. São proporcionados resultados de pesquisa sobre os tradutores, com maior ênfase nas quatro traduções brasileiras. Apresenta-se também um catálogo com detalhes editoriais das setenta e duas edições já publicadas. Após uma revisão teórica dos mais recentes estudos em historiografia da tradução, é oferecida a metodologia utilizada neste trabalho, adaptada para realizar as pesquisas historiográficas dentro da realidade brasileira.

Palavras-chave: Quixote, Cervantes, tradutores, historiografia da tradução, recepção do Quixote no Brasil

THE TRANSLATORS OF DON QUIJOTE PUBLISHED IN BRAZIL This article describes the history of the six translations of Don Quijote published in Brazil, from the first edition of 1942 up to the most recent in 2008, emphasizing the four Brazilian translations. It also catalogues the seventy-two editions of Don Quijote. After studying recent studies of translation historiography, the article then presents the methodology used in this research.

Keywords: Quijote, Cervantes, translators, translation historiography, Quijote's reception in Brazil

\section{ALGUNS ASPECTOS DA PRESENÇA DE EDGAR ALLAN POE NO BRASIL Denise BOTTMANN}

Este artigo trata da presença de Edgar Allan Poe no Brasil, desde o começo do século XX até o presente, abordando três aspectos específicos: a primeira edição brasileira de contos de Poe, as traduções de The Black Cat e as várias antologias de seus contos enfeixados sob o mesmo título de Histórias extraordinárias. 
Palavras-chave: Edgar Allan Poe, tradução, The Black Cat, Histórias Extraordinárias

\section{THE PRESENCE OF REGARDING EDGAR ALLAN POE IN BRAZIL}

My main concern in this present paper has been to trace the very first edition of tales by Edgar Allan Poe published in Brazil in the early 20th century. In addition, I have tried to list all distinct translations of The Black Cat which I could find since its first appearance in Brazil. Finally, I have pointed out the surprising profusion of rather different anthologies bearing the same title of Histórias Extraordinárias.

Keywords: Edgar Allan Poe, translation, The Black Cat, Histórias Extraordinárias

\section{HISTÓRIA DA AUTOTRADUÇÃO: OS CASOS DE ANDRÉ BRINK E JOÃO UBALDO RIBEIRO \\ Maria Alice G. ANTUNES}

Este artigo apresenta um breve histórico da autotradução. Na primeira parte, apresenta um resumo da história da autotradução desde Flavius Josephus (século I) até o século XIX mostrando as considerações de Julio Cesar Santoyo, Helena Tanqueiro e Jan Walsh Hokeson e Marcella Munson sobre o tema. Em seguida, apresenta um registro dos autotradutores dos séculos XX e XXI, destacando os casos do escritor sul-africano André Brink e o do brasileiro João Ubaldo Ribeiro. O artigo ressalta as particularidades de cada caso para demonstrar como a autotradução é uma atividade exercida de maneiras distintas que dependem de forma direta, por exemplo, do autor que realiza a tradução.

Palavras-chave: autotradução, história, estudo de caso, André Brink, João Ubaldo Ribeiro

\section{A SHORT HISTORY OF SELF-TRANSLATION: THE CASES OF ANDRÉ BRINK AND JOÃO UBALDO RIBEIRO}

This article presents a short history of self-translation. The presentation starts with a summary of self-translation from the 1st to the $19 t^{h}$ century based on the work of scholars such as Julio Cesar Santoyo, Helena Tanqueiro, Jan Wash Hokeson and Marcella Munson. It goes on to present a short description of authors who translated their own texts during the 20th and 21st centuries. The study highlights the cases of the South African writer André Brink and the Brazilian writer João Ubaldo Ribeiro to demonstrate how self-translation takes place differently in different contexts.

Keywords: self-translation, history, case study, André Brink, João Ubaldo Ribeiro

\section{DA TEORIA ELOCUTIVA DA TRADUÇÃO RENASCENTISTA Mauri FURLAN}

As reflexões produzidas no Renascimento europeu sobre a prática da tradução no período constituem fecundo material para o estudo de sua concepção da tradução. A partir da análise de tais textos à luz da elocutio - o sistema operador da retórica clássica, que plasmava a concepção histórica da linguagem -, apresentamos elementos para a constituição de uma teoria elocutiva da tradução renascentista. Tais estudos também 
revelam que o Renascimento assentou as bases da tradutologia moderna, mormente pela valorização e respeito ao texto original e sua correspondente reprodução na língua tradutora.

Palavras-chave: Renascimento, teoria elocutiva da tradução, história da teoria da tradução

\section{ON THE ELOCUTIVE TRANSLATION THEORY OF THE RENAISSANCE}

Reflections on translation practice produced in the European Renaissance are fruitful material for the study of its conception of translation. Based on the analysis of such texts in light of elocution, the operating system of classical rhetoric that shaped the historical conception of language, we offer suggestions for the constitution of an elocutive translation theory of the Renaissance. Such studies also reveal that the Renaissance laid the basis of modern translation studies, chiefly due to its high esteem and respect for the source text and the its corresponding reproduction in the target language.

Keywords: Renaissance, elocutive translation theory, history of translation theory 